\title{
Investigation of the ferric ions complexes with biolygands of probiotic origin
}

\author{
Antonina Kapustian, Natalia Cherno \\ Odesa National Academy of Food Technologies, Odesa, Ukraine
}

\section{Keywords:}

Ferric ion

Chelate

Bioligand

Peptidoglycan

Muropeptide

\section{Article history:}

Received 12.06.2019

Received in revised

form 23.12.2019

Accepted 30.03.2020

\section{Corresponding author:}

Antonina Kapustian

E-mail:

fst.journal@ukr.net

\section{DOI:}

$10.24263 / 2304-$

974X-2020-9-1-5

\section{Abstract}

Introduction. The peculiarities of obtaining stable, easily digestible and safe ferric ion complexes with bioligands of the probiotic origin and their characteristics have been investigated.

Materials and research methods. As bioligands, the products of metabolism and processing of biomass Lactobacillus delbrueckii subsp. Bulgaricus B-3964, namely, lactic acid, amino acids, low molecular weight peptides and muropeptides, were used. The destruction of biomass peptidoglycans was performed by alternating treatment of sonication and papain. The progress of complexation was monitored using the turbidimetry method.

Results and discussion. The destruction of biomass peptidoglycans, performed by alternating sonication and the papain enzyme preparation, resulted in a mixture of amino acids, low molecular weight peptides and muropeptides, the concentration of which was $10.24 \mathrm{mg} / \mathrm{cm}^{3}, 6.45 \mathrm{mg} / \mathrm{cm}^{3}$ and $2.25 \mathrm{mg} / \mathrm{m}^{3}$ respectively. Lactic acid was isolated from the culture fluid by crystallization of calcium lactate. Three polydentate systems were used to form $\mathrm{Fe}^{3+}$ complexes: peptidoglycan destruction products; lactic acid; a mixture of degradation products and lactic acid. It was found that the bioligand systems under study bind $\mathrm{Fe}^{3+}$ ions in the amounts of 32, 40 and $46 \mathrm{~mol} / \mathrm{dm}^{3} \cdot 10^{-2}$ respectively. Electrostatic and coordination interactions are involved in the formation of the complex of iron (III) and probiotic bioligands. The behavior of complexes at different $\mathrm{pH}$ values and temperatures was studied. Most stable is the complex formed with the participation of the bioligands system containing the products of peptidoglycans degradation and lactic acid. Such system of bioligands provides the formation of ferric ions chelate complexes, stable in the $\mathrm{pH}$ range of $1-10$ units. Obtained complex is a promising ingredient of dietary supplements and dietic products whose technology involves high-temperature processing. That was proven that, the complex is stable in the temperature range of $20-122{ }^{\circ} \mathrm{C}$. When the temperature reaches $122-125^{\circ} \mathrm{C}$, the mass loss is $3 \%$ for the complex and $14 \%$ for the mechanical mixture. In the temperature range of $122-178{ }^{\circ} \mathrm{C}$, an endothermic reaction is observed during the thermal treatment of the complex, and no thermal effects are observed during the mechanical mixture treatment. The weight loss of the complex in this temperature range is $22 \%$, mechanical mixture $-16 \%$. The presence of an endothermic peak on the differential thermal analysis curve of the complex may indicate the presence in its structure of chelate bonds, and during their destruct the enthalpy changes are occurred.

Conclusion. The research results indicate the effectiveness of the use of polydendant mixed ligand systems of probiotic origin for complexation with ferric ions. 


\section{Introduction}

Iron is one of the most important trace elements that is part of more than 100 enzymes of the human body, participates in respiration, hematopoiesis, immunobiological processes, redox reactions, etc. [1]. Insufficient iron supply to the body can provoke iron deficiency anemia (IDA). It is a disease of the blood system caused by iron deficiency in the body [1,2]. IDA is accompanied by changes in metabolism parameters, a decrease in hemoglobin concentration, which can lead to disorders of the cardiovascular, nervous system, decrease in women's reproductive function, changes in intelligence and behavioral moods, chronicity of various diseases, etc. [3, 4].

\section{Analysis of recent research and publications}

As is known [1], food contains 2 types of iron - heme (red meat) and non-heme, or ionized (vegetables, fruits, cereals). Moreover, non-heme iron covers $70 \%$ of the human body's need for iron.

The entry of iron into the body occurs through the intestinal mucosa, where it is adsorbed by food enterocytes (the common name of epithelial cells lining the intestinal mucosa, which are highly specialized cells that coordinate the absorption and transport of iron). The absorption of iron in the intestine occurs in three main ways: with the transporter of divalent cations, as part of the mobilferrin integrated complex, as well as a special way for the absorption of heme iron from food (Figure 1) [2,3].

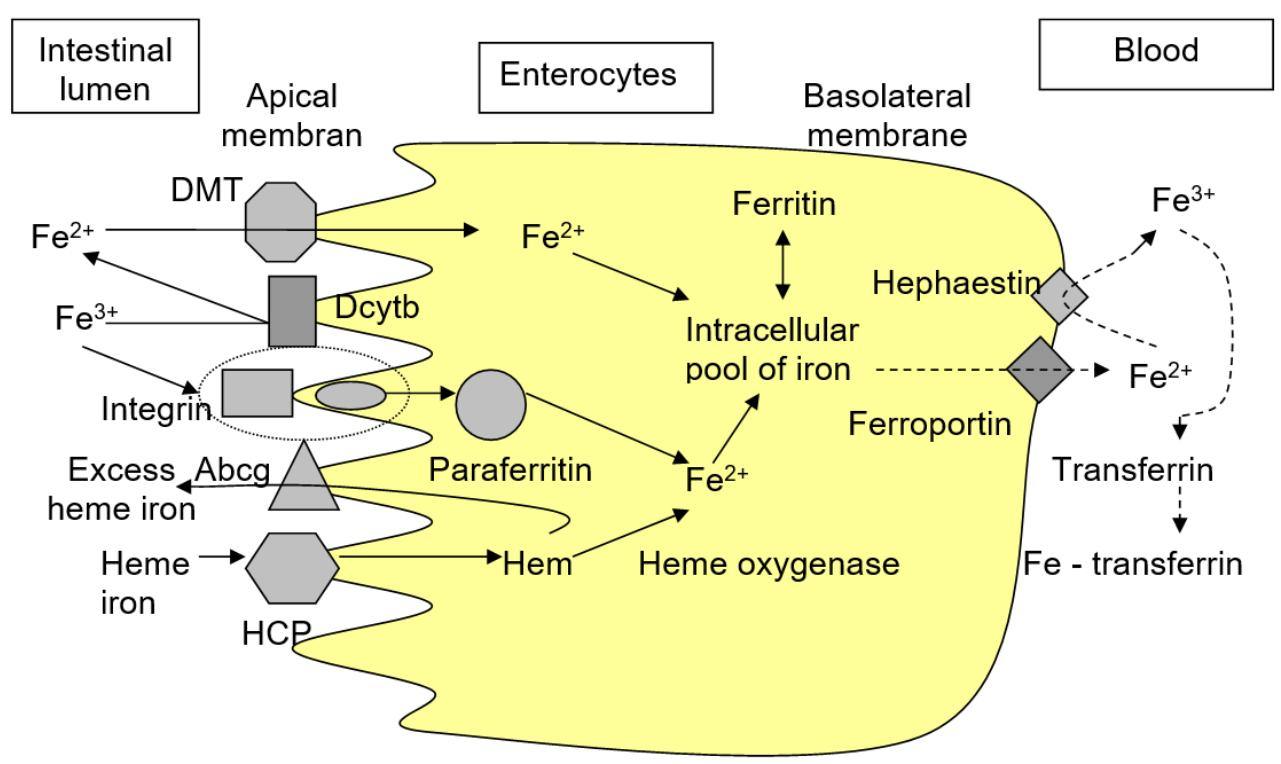

Figure 1. Scheme of iron transport in the enterocyte [2] 
Inorganic, organic and multivitamin preparations in oral form are usually used to replenish iron deficiency (Figure 2) [4].

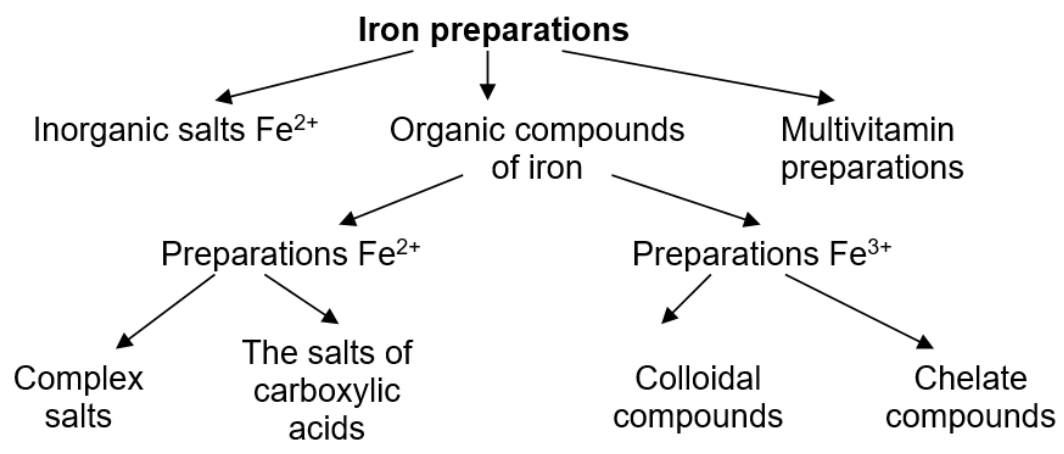

Figure 2. Classification of iron preparations [4]

The use of inorganic preparations in the ferrous form $\left(\mathrm{Fe}^{2+}\right)$ can provoke a number of complications. In the gastrointestinal tract, the ferrous ion is oxidized to the ferric-ion, inducing the appearance of a free electron, resulting in the generation of free radicals that disrupt DNA synthesis, affect the activity of several enzymes, cause the peroxidation of polyunsaturated lipids in cell membranes [4]. Moreover, increased concentrations of ferrous iron in the intestine contribute to the its passive transport of into enterocytes, which leads to the entry of toxic ions into the cells of the intestinal mucosa and can cause their death. Direct cytotoxic effect of ferrous ions on cells of different organs, especially brain and liver, was also noted [3]. To counteract these disadvantages, to ferrous drugs additionally include antioxidants (such as ascorbic acid), or fix $\mathrm{Fe}^{2+}$ ions on special matrices that cause their prolonged release [4].

Ferric ion salts $\left(\mathrm{Fe}^{3+}\right)$ have better solubility and higher elemental iron content than ferrous salts, but $\mathrm{Fe}^{3+}$ has a higher charge/radius ratio than $\mathrm{Fe}^{2+}$ ion, which causes a significant degree of hydrolysis of iron (III) salts $[2,5]$. During the hydrolysis of salts of ferric ions, the formation of insoluble $\mathrm{Fe}(\mathrm{OH})_{3}$ hydroxide occurs. Thus, inorganic agents containing $\mathrm{Fe}^{3+}$ are more likely to be converted to ferric hydroxide in an alkaline medium of the intestine, which makes it impossible for them to absorb. Such the ferric properties complicate its use as an oral agent for the correction of IDA [2, 4].

Organic iron compounds are more widely used as a means of correcting iron deficiency $[4,5]$. Thus, the use of an organic $\mathrm{Fe}^{2+}$ complex with two nicotinamide molecules is known [4]. Ferum (II) salts and carboxylic acids, namely fumaric, lactic, gluconic, have also been used as they have been shown to have protective properties similar to those of ascorbic acid. The problem of introduction of ferric ion into the body was solved in the group of chelating agents. There is an agent based on the chelate complex of ferum protein succinylate, in which the ligands provide the stability of the ferric ion, and the stability constants are not less than in the ferric hydroxide. This provides preservation of $\mathrm{Fe}^{3+}$ in a soluble state in the intestinal lumen and increases the likelihood of its absorption $[4,6]$.

There are agents to combat IDA based on insoluble iron oxide in colloidal solution. In the micelles of such a colloidal solution, insoluble $\mathrm{Fe}(\mathrm{OH})_{3}$ was used as the nucleus of the micelles, and the dense layer was created by carbohydrate compounds, such as maltose, sucrose, sorbitol, isomaltose [4]. 
Despite some advances in the development of effective anti anemia agents, the search for new, more perfect forms of iron for oral use is still ongoing [7, 8]. Since iron in the living body is always in the composition of bioorganic complexes with amino acids, proteins and other bioligands $[2,4]$, the use of mixed ligand systems to obtain safe soluble easily digestible forms of non-toxic ferric ions is worthy of attention [9]. The study of mixed ligand complexes of biometals has become widespread, the methods of obtaining and characteristics of some of them are described in the literature [10-12]. Both natural and synthetic compounds are used as bioligands, but there is no information in the literature on the possibility of using metabolism products and processing of probiotic bacteria to produce mixed ligand systems containing iron [13-15]. Despite the extensive experience and production of probiotic cultures cultivation, this idea is very relevant [16-17]. The culture fluid contains a large number of metabolites, in particular organic acids, capable of chelation with biometals [18, 19]. With the disintegration of probiotic cells, degradation products of the peptidoglycans of their cell walls can be obtained, namely, amino acids, low molecular weight peptides, muropeptides, which also contain functional groups capable to form ionic and coordination bonds with metal ions. In addition, the substances of the muropeptide series have their own physiological activity - they are powerful immunotropic compounds [20-21].

The purpose of this work is obtaining and characteristic of the ferric ions complexes with metabolites and low molecular weight degradation products of peptidoglycans of Lactobacillus delbrueckii subsp. Bulgaricus B-3964.

\section{Materials and methods}

\section{Materials}

Biomass (BM) of lactic acid bacteria Lactobacillus delbrueckii subsp Bulgaricus B-3964 with a concentration of $4.8 \cdot 10^{9} \mathrm{CFU} / \mathrm{cm}^{3}$ from the collection of the Scientific and Production enterprise Ariadna (Odesa), papain with proteolytic activity of $10 \mathrm{Un} / \mathrm{mg}$ (Swanson Health Products, USA), $\mathrm{FeCl}_{3} \cdot 6 \mathrm{H}_{2} \mathrm{O}$ h (China) were used for the research.

\section{Obtaining degradation products of peptidoglycans Lactobacillus delbrueckii subsp. Bulgaricus B-3964}

The isolation of cells from the culture fluid was carried out by centrifugation for $15 \mathrm{~min}$ at $8000 \mathrm{~min}^{-1}$. The precipitated cells were washed with distilled water, resuspended and carried out the ultrason treatment using ultrasonic baths "PSB-1335-05" with a working frequency of $40 \mathrm{kHz}$, duration of the treatment was $300 \mathrm{~s}$. The enzymatic destruction of BM cell walls was carried out by papain treatment at $37{ }^{\circ} \mathrm{C}$ and $\mathrm{pH}=7.4$. The enzyme: substrate ratio (BM solids content) was 1:200, the incubation time of the reaction mixture was 300 min. The enzymatic hydrolysis was stopped by emergency heating to a temperature of $100{ }^{\circ} \mathrm{C}$, the mixture was cooled, the liquid phase was separated from the solid by centrifugation for $10 \mathrm{~min}$ at $8000 \mathrm{~min}^{-1}$. In the liquid phase, the content of free amino acids was controlled by formol titration method [22]. The content of low molecular weight peptides (LMWP) was determined by the Benedict method [22] after precipitation of high molecular weight proteins by $10 \%$ trichloroacetic acid. The content of muropeptides was determined after purification of the hydrolysate on an ion exchange column with cation exchanger [23] and the subsequent determination of the carbohydrate component in the composition of muropeptides by the Antron method [24]. 


\section{Lactic acid isolation}

The isolation of lactic acid from the culture fluid was performed by a classical method, which included crystallization of calcium lactate with subsequent processing of crystals with sulfuric acid and removal of insoluble calcium sulfate precipitate [25].

\section{Ferric complexes preparation}

The complexes were obtained by combining solutions of bioligands and $\mathrm{FeCl}_{3} \cdot 6 \mathrm{H}_{2} \mathrm{O}$ with vigorous stirring for $180 \mathrm{~s}$, the temperature of complexation was $40{ }^{\circ} \mathrm{C}$. Iron-containing complexes were obtained by combining $\mathrm{FeCl}_{3} \cdot 6 \mathrm{H}_{2} \mathrm{O}$ solutions with: hydrolysate of Lactobacillus delbrueckii subsp. Bulgaricus B-3964 (Complex I), lactic acid at a concentration of $10 \mathrm{mg} / \mathrm{cm}^{3}$ (Complex II); hydrolysate and lactic acid with concentration $5 \mathrm{mg} / \mathrm{cm}^{3}$ in the mixture (Complex III). The complex formation ability of $\mathrm{Fe}^{3+}$ ions with the bioligands was determined by a turbidimetric method in the presence of $\mathrm{Na}_{2} \mathrm{CO}_{3}$ on a spectrophotometer SF-2000 at $450 \mathrm{~nm}$ [26]. Different volumes of $0.5 \mathrm{n} \mathrm{FeCl}_{3} \cdot 6 \mathrm{H}_{2} \mathrm{O}$ were added to aliquots of mixtures containing bioligands, mixed and left for $180 \mathrm{~s}$ for complete chelation. $1 \mathrm{~N} \mathrm{Na}_{2} \mathrm{CO}_{3}$ was then added to the solutions to achieve a $\mathrm{pH}$ of 7 units. Under these conditions, $\mathrm{Fe}^{3+}$ ions, which did not participate in the complexation, interact with sodium carbonate to form insoluble $\mathrm{Fe}(\mathrm{OH})_{3}$ particles, which provoke turbidity of the system [27].

\section{Complexes pH-stability study}

The behavior of the complexes was investigated in the range of $\mathrm{pH}$ values of the medium 1-10 units. The concentration of $\mathrm{Fe}^{3+}$ was determined by the thiocyanate method [28]. The required $\mathrm{pH}$ was achieved using standard $\mathrm{NaOH}$ and $\mathrm{H}_{2} \mathrm{SO}_{4}$ solutions. The stability of the chelate complexes was calculated by the formula (1):

$$
C=\frac{a-b}{a} 100, \%
$$

where $a$ is the total amount of $\mathrm{Fe}^{3+}$ ions in the complex, $\mathrm{mg} / \mathrm{cm}^{3} ; b$ is the amount of $\mathrm{Fe}^{3+}$ ions released into the reaction medium, $\mathrm{mg} / \mathrm{cm}^{3}$.

\section{Complexes thermal stability study}

The studies were performed using the differential scanning calorimetry (DSC) method. DSC thermograms were obtained in the temperature range of $25-250{ }^{\circ} \mathrm{C}$ at a constant heating rate of $5{ }^{\circ} \mathrm{C} / \mathrm{min}$ on a Derivatorgaph Q1500-D calorimeter. In order to determine under what conditions the complete decomposition of the samples would take place, the heating was continued to a maximum temperature of $450{ }^{\circ} \mathrm{C}$. A $500 \mathrm{mg}$ portion was placed in a ceramic crucible. The accuracy of determining the temperature was $\pm 1^{\circ} \mathrm{C}$, the thermal effect $- \pm 3 \%$.

IR spectra of samples were recorded in the range of wavelengths from 4000 to $400 \mathrm{~cm}^{-}$

${ }^{1}$ in a spectrometer with a Fourier transformer FTIR IR Affinity-1, Shimadzu (Japan) [29]. 


\section{Results and discussion}

\section{Preparation and characterization of mixed-ligand complexes of ferric ions}

Probiotic bioligands, namely, peptidoglycan degradation products and metabolism of Lactobacillus delbrueckii subsp. Bulgaricus B-3964, were used to form $\mathrm{Fe}^{3+}$ chelate complexes. Destruction of peptidoglycans of cell walls of BM was performed by the procedure above. As a result, a mixture of amino acids, LMWPs and muropeptides was obtained, the concentration of which was $10.24 \mathrm{mg} / \mathrm{cm}^{3}, 6.45 \mathrm{mg} / \mathrm{cm}^{3}$ and $2.25 \mathrm{mg} / \mathrm{cm}^{3}$, respectively. An effective chelating agent, namely lactic acid, that is a metabolism product, was also isolated from the BM culture fluid. As a result of the manipulations above, a solution of lactic acid at a concentration of $10 \%$ was obtained. A mixture of amino acids, LMWPs, muropeptides and lactic acid is a mixed ligand system that can cause the formation of stable chelate complexes of biometals, but it is difficult enough to determine the exact denticity of such system, that complicates the calculation of the required amount of metal in inorganic form for its complete chelation at complex formation $[9,27]$.

As a rule, the synthesis of biometals chelate complexes is carried out with a known composition of lygands of definite denticity. This allows to take on to the complexation reaction required amount of metal, which provides the effect of complete chelation [7, 27]. In our case, it was necessary to determine in what form the metal is in the system of biological agents: organic or inorganic. The classical methods for determining the concentration of a metal ion in a reaction medium are unjustified because the reagents used are sufficiently aggressive. This may cause the destruction of the ionic, coordination bonds of the complexes, which will not provide reliable results and will not allow to determine what form the metal was in the system. Therefore, the determination of free $\mathrm{Fe}^{3+}$ ions in the reaction medium was carried out using nephelometry, namely, by determining the turbidity of the system, the presence of which was provided by the reaction products of free ferric ions and sodium carbonate. Three probiotic bioligand systems were used for the studies: low molecular weight hydrolysis products of peptidoglycans (Complex I), lactic acid (Complex II) and their mixture (Complex III). The concentration of additional ligands for complexation was chosen based on theoretical quantum-chemical ideas about possible configurations of $\mathrm{Fe}^{3+}$ chelate complexes. The results of the studies are presented in Figure 3.

As can be seen from Figure 3, the turbidity of mixed ligand systems in the presence of $\mathrm{Fe}^{3+}$ and $\mathrm{Na}_{2} \mathrm{CO}_{3}$ ions is minimally stable ( 0.08 opt. Units) until a certain concentration of metal is reached in the mixture. For the systems under study, this value has a significant difference. Thus, the rapid turbidity growth of Complex I system occurs at concentrations of $\mathrm{Fe}^{3+}$ ions in a mixture of $32 \mathrm{~mol} / \mathrm{dm}^{3} \cdot 10^{-2}$, Complex II $-40 \mathrm{~mol} / \mathrm{dm}^{3} \cdot 10^{-2}$, Complex III -40 $\mathrm{mol} / \mathrm{dm}^{3} \cdot 10^{-2}$. Such behavior of the investigated systems indicates that, before reaching these concentrations, the metal is in bound state in the composition of mixed ligand complexes, that makes impossible its interact with the sodium carbonate present in the system and the appearance of insoluble ferum hydroxide, which causes turbidity. From figure 3 implies that Complex III contains the largest amount of bound metal. This is because the denticity of the mixed ligand system of this complex is the highest, based on the total concentration of all its components $[7,30]$. 


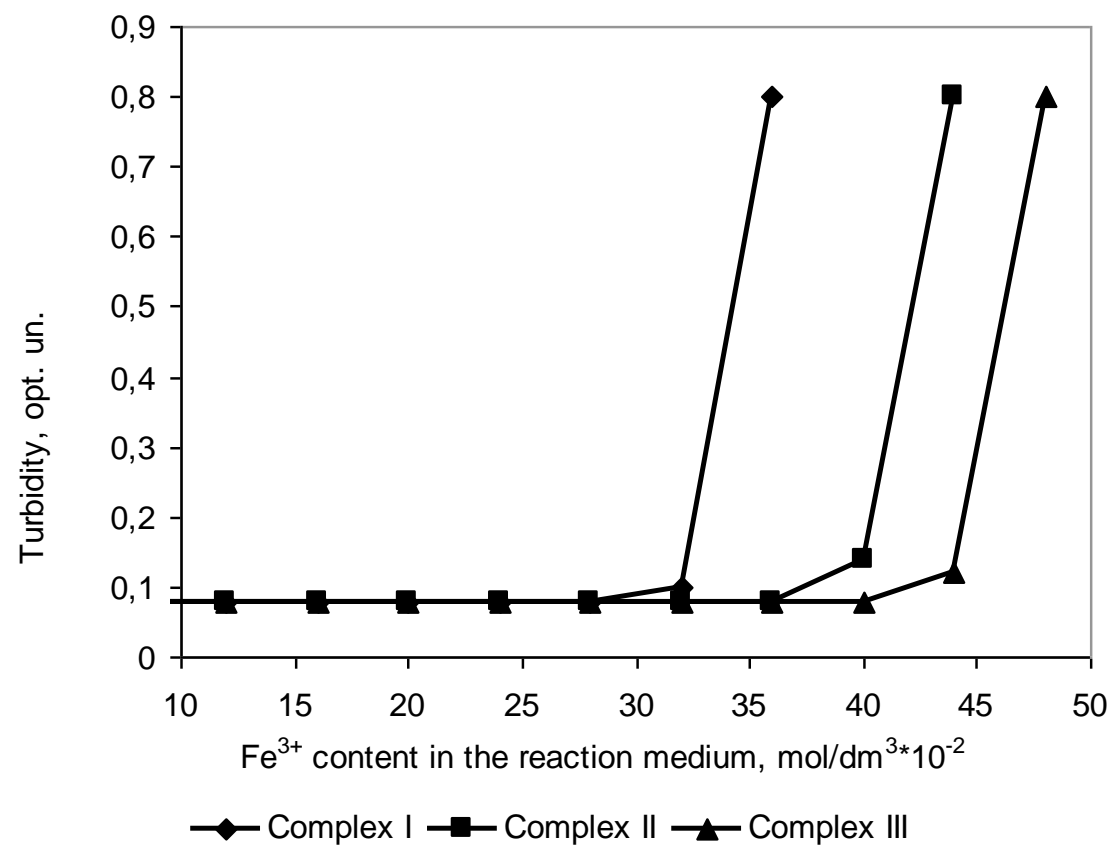

Figure 3. Dependence of the turbidity of mixed ligand system of probiotic origin on the content of $\mathrm{Fe}^{3+}$ ions in the presence of $\mathrm{Na}_{2} \mathrm{CO}_{3}$

IR spectroscopy was used for a deeper study of the chemical structure of the complex. The following samples were studied by IR spectroscopy: 1 - bioligands (a mixture of peptidoglyclic hydrolysis products and lactic acid); 2 - a complex of ferric ions with bioligands (Figure 4). Ferric ions and the mechanical mixture of the complex components were not investigated by IR spectroscopy, since the $\mathrm{FeCl}_{3} \cdot 6 \mathrm{H}_{2} \mathrm{O}$ compound is very hygroscopic, that complicates the analysis and may affects on the correct interpretation of the results.

When comparing the IR spectra of bioligands and the resulting complex, there is a difference between the absorption bands. In particular, a significant band broadening in the region of $3000-3500 \mathrm{~cm}^{-1}$ was observed, which corresponds to the valence vibrations of primary amino groups of amino acids, protonated amino groups, free hydroxyl groups [29], metal complexes of amino acids $\left(3200-3400 \mathrm{~cm}^{-1}\right)$ [31]. In addition, a band at frequencies of $2933 \mathrm{~cm}^{-1}$ appears in the spectrum of the complex, which corresponds to the fluctuations of the bound $\mathrm{OH}$ - groups [29], which may confirm their participation in the formation of the complex. The spectra lack absorption bands at frequencies of $1700-1760 \mathrm{~cm}^{-1}$, which are characteristic of vibrations of the carboxyl group $(-\mathrm{COOH})$, but there are peaks in the range of $1550-1650 \mathrm{~cm}^{-1}$, which correspond to the vibrations of carboxylate anions $\left(-\mathrm{COO}^{-}\right)$[29]. 


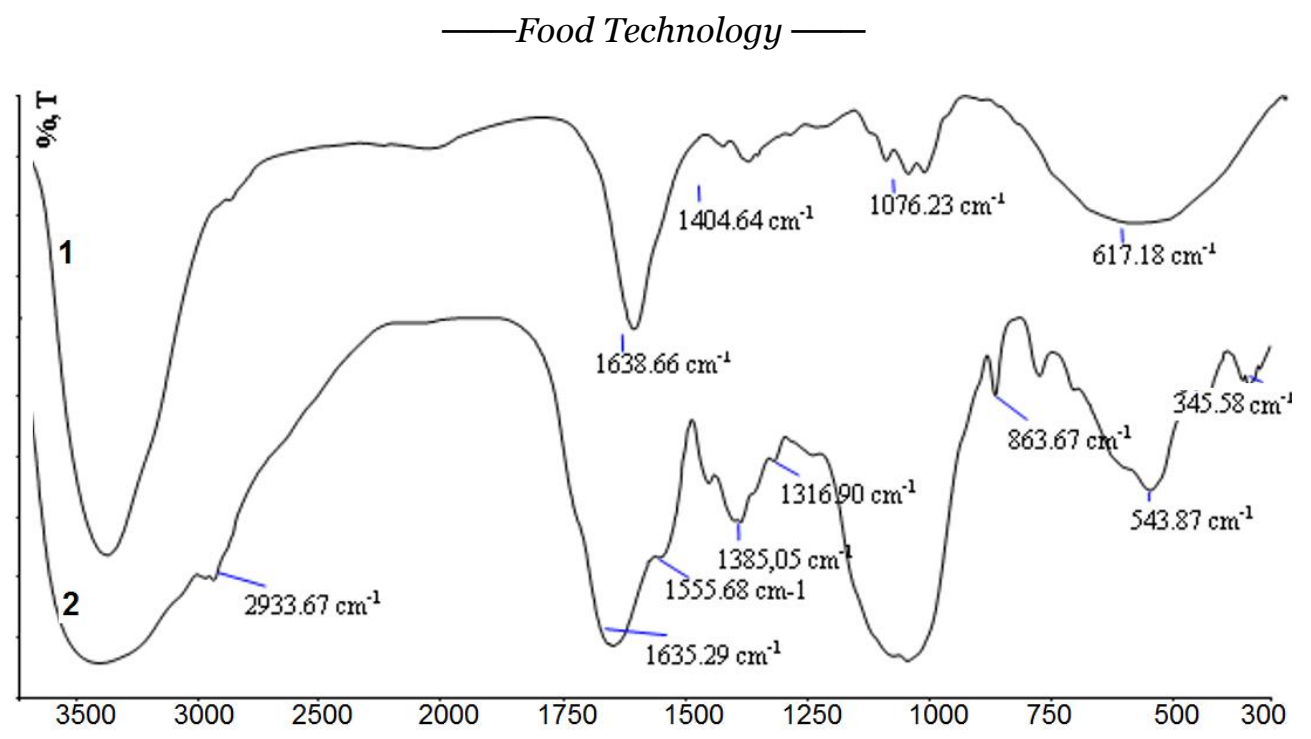

Figure 4. IR spectra of bioligands (1) and iron complex (2)

The presence of functional groups of bioligands in ionic form proves that electrostatic interactions can take part in the formation of the complex. In the spectrum of the complex, unlike the spectrum of bioligands, there is an absorption band at $1040 \mathrm{~cm}^{-1}$. Its presence may indicate the formation of coordination bonds with amides [31]. In the low-frequency region of the complex spectrum there are bands $\left(345 \mathrm{~cm}^{-1}, 540 \mathrm{~cm}^{-1}\right)$, corresponding to the fluctuations of the ferrum. Moreover, the absorption at frequencies of $540 \mathrm{~cm}^{-1}$ is somewhat offset compared to the inorganic forms of the ferrum, for which oscillations in the region $460-500 \mathrm{~cm}^{-1}$ are characteristic [31]. The IR spectra of the studied materials also show that metal ions interact with the lactic acid $\mathrm{OH}$ - group. For example, in the complex obtained there is a significant increase in the intensities of the peaks in the region of $1100-1160 \mathrm{~cm}^{-1}$, which indicates the coordination interaction of metal ions with the $\mathrm{OH}$-groups [31].

Thus, since the spectra of the obtained metal complex, as compared to the IR spectrum of the starting material, show an increase in some absorption bands and the formation of new peaks, it can be assumed that the incorporation of ferric ions into the structure of bioligands does not occur mechanically, but as a result of ionic and coordination interactions with their functional groups.

Since chelate complexes of ferric ions with products of metabolism and processing of BM Lactobacillus delbrueckii subsp. Bulgaricus B-3964 is planned to be used as dietary supplements and biologically active food ingredients, it is advisable to study their behavior at different $\mathrm{pH}$ values (Figure 5) and temperatures (Figure 6). 


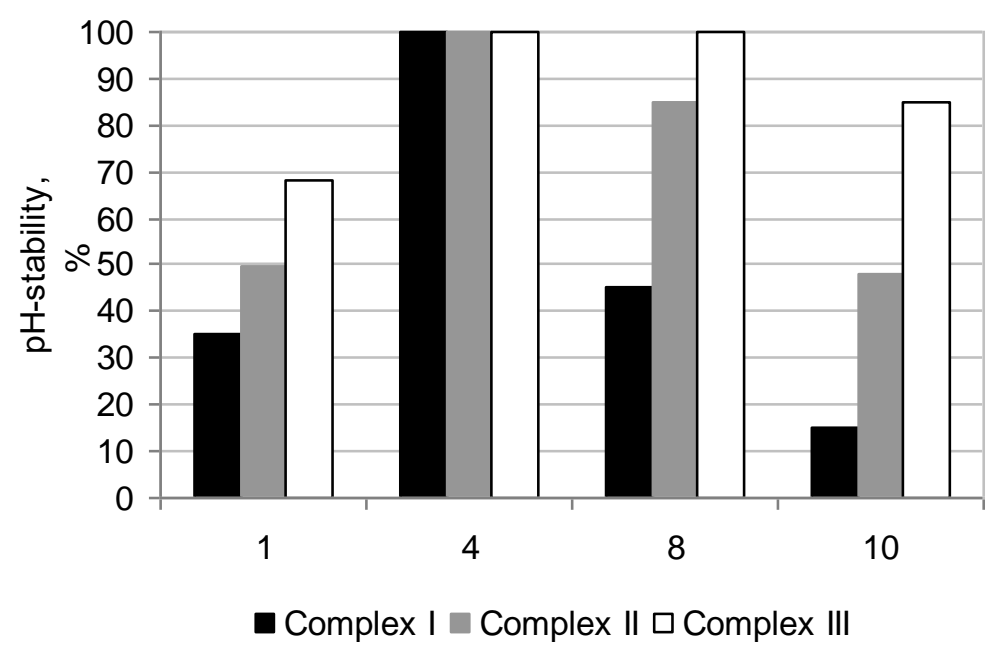

Figure 5. pH-stability of complexes

Based on the data of Figure 5, the complex, formed with the participation of degradation products of peptidoglycans and metabolites of $\mathrm{BM}$, has the greatest stability at different $\mathrm{pH}$ values. According to the literature, the mixed ligand polydentate systems exactly can cause a stable "chelating effect". Complexation of metals with polydentante ligands is more advantageous in terms of thermodynamics than monodentant ligands. The $\mathrm{Fe}^{3+}$ complexing agent has $\mathrm{d}^{2} \mathrm{sp}^{3}$ hybridization of atomic orbitals [30] and may cause the formation of an octahedral complex with bioligands, which also explains the considerable stability of the complexes in environments with different ion activity. The stability of the obtained complexes in the $\mathrm{pH}$ range of $8-10$ allows us to predict the possibility of the presence of a ferric ion in the dissolved state in the small intestine, where its absorption by enterocytes occurs [2-3]. The stability of chelates at elevated $\mathrm{pH}$ values is also due to the competition between metal ions and proton per biolygand anion [30]. Therefore, the resulting chelate structures are stable in the range of $\mathrm{pH}$ values inherent in most food systems, which makes the prospect of their use as biologically active food ingredients.

To predict the behavior of the obtained chelate complexes in the composition of food systems that can be subjected to temperature treatment, their analysis was performed by the DSC method (Figure 6a, b). For this study Complex III and mechanical mixture of its components were used. 

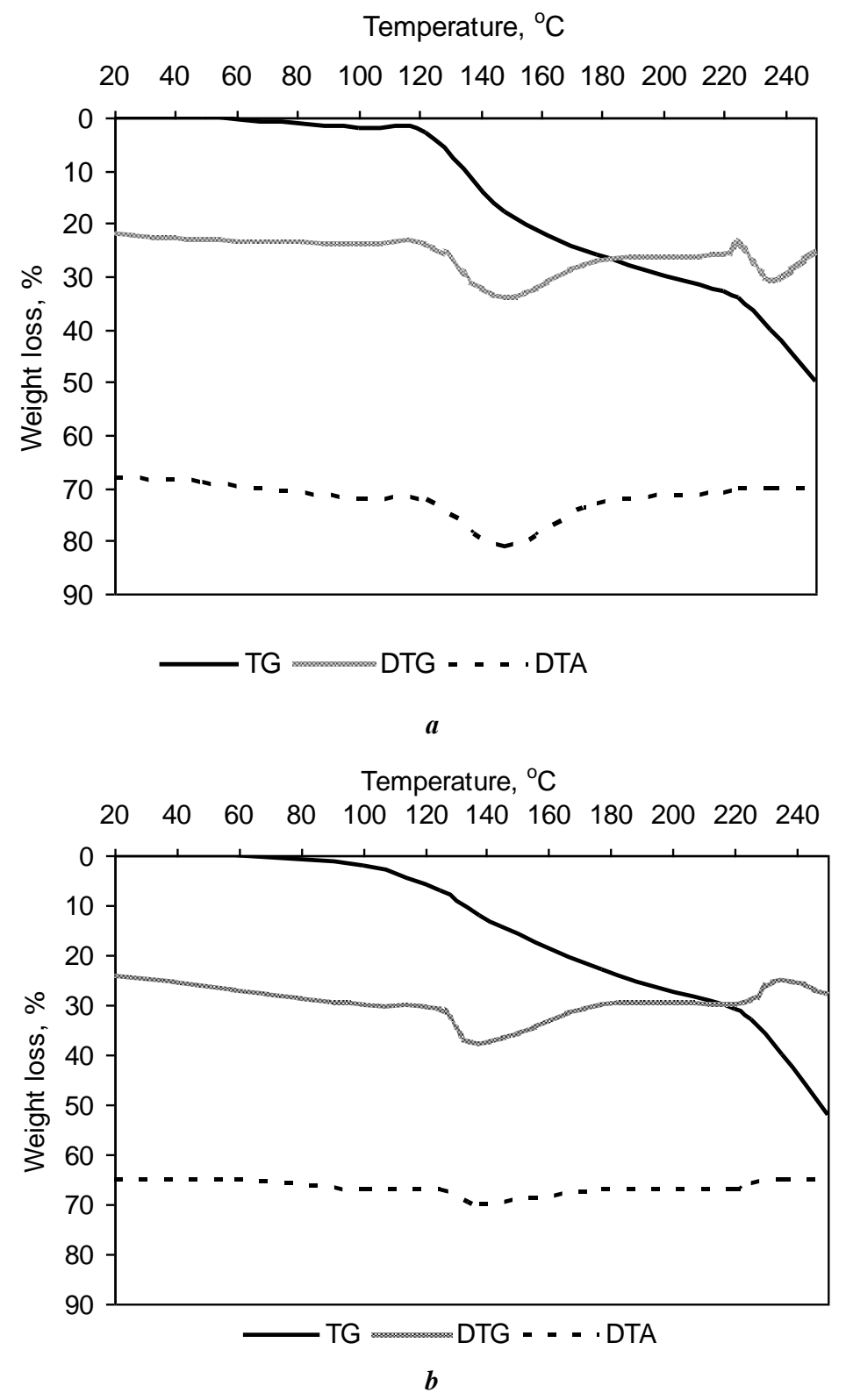

Figure 6. Termograms DSC:

a - complex; $b$ - a mechanical mixture of complex components

TG is the thermogravimetric curve that characterizes the mass loss of the sample, depending on the temperature;

DTG is the curve of differen-tial thermogravimetry based on the registration of the rate of change in mass with continuous heating, which is a more accurate interpretation of the TG curve;

DTA is the curve of differential thermal analysis, which serves to fix the presence of certain thermal effects. 
In Figure 6a the curves TG, DTG, and DTA obtained from the DSC analysis of the complex are shown, and in Figure. $6 \mathrm{~b}$ - the curves of the mechanical mixture (MM) of the complex components. When comparing the DSC analysis data, it can be stated that the initial weight loss of the samples begins at a temperature of $49{ }^{\circ} \mathrm{C}$ during the thermal treatment of the complex and at $59{ }^{\circ} \mathrm{C}$ during the thermal treatment of the MS. These figures show that the first mass loss is not accompanied by thermal effects, indicating that at these temperatures does not destroy the chelate bonds of the complex, which can provoke a change in the enthalpy of the process and the appearance of peaks in the DTA curves. Therefore, the first mass loss is associated with the removal of free moisture in the samples. When the temperature reaches $122-125{ }^{\circ} \mathrm{C}$, the mass loss is $3 \%$ for the complex and $14 \%$ for the MM. In the temperature range of $122-178{ }^{\circ} \mathrm{C}$, an endothermic reaction is observed during the thermal treatment of the complex, and no thermal effects are observed during the mechanical mixture treatment. The weight loss of the complex in this temperature range is $22 \%, \mathrm{MM}-$ $16 \%$. The presence of an endothermic peak on the DTA curve of the complex may indicate the presence in its structure of chelate bonds, and during their destruct the enthalpy changes are occurred.

\section{Conclusions}

1. The results of studies indicate the effectiveness of the use of polydendant mixed ligand systems of probiotic origin for complexation with ferric ions.

2. The study of the complex of iron (III) and bioligands of probiotic origin by IR spectroscopy showed that electrostatic and coordination interactions are involved in its formation.

3. According to studies, a system of bioligands containing the peptidoglycan degradation products and metabolites of lactobacilli, provides the formation of chelate complexes of ferric ions, stable in a wide range of $\mathrm{pH}$ environments (1-10 units).

4. The DSC method shows that the obtained complex is a promising ingredient of dietary supplements and wellness products whose technology involves high-temperature processing, since the complex is stable in the temperature range of $20-122{ }^{\circ} \mathrm{C}$.

5. The presence in the composition of these complexes of low molecular weight muropeptides with high immunotropic activity, allows to classify these compouds to the category of polyfunctional.

The prospect of further research is to study the physiological activity of the resulting complex in animal experiment.

\section{References}

1. Vatutin M.T. ta in. (2012), Rol zaliza v orhanizmi liudyny, Visnyk KhNU imeni V.N. Karazina, 1024, pp. 74-80.

2. Shafran L.M., Pyihteeva E.G., Shitko E.S. (2012), Sistema transporta zheleza v kletkah: fiziologiya i toksikologiya pogloscheniya iz pischi enterotsitami kishechnika, SuchasnI problemi toksikologii, 2, pp. 5-16.

3. Jesse P. Goff (2018), Invited review: Mineral absorption mechanisms, mineral interactions that affect acid-base and antioxidant status, and diet considerations to improve mineral status, Journal of Dairy Science, 101(4), pp. 2763-2813, DOI: 10.3168/jds.2017-13112. 
4. Kruglov D.S. (2017), Lekarstvennyie sredstva primenyaemyie dlya profilaktiki i lecheniya zhelezodefitsitnyih sostoyaniy, Nauchnoe obozrenie. Meditsinskie nauki, 4, pp. 26-41.

5. Tong Liu et al. (2019), Preparation and Characterization of a Novel PolysaccharideIron(III) Complex in Auricularia, BioMed Research International, 2019, DOI: 10.1155/2019/6416941.

6. Yanan Li, Han Jiang, Guangrong Huang (2017), Protein Hydrolysates as Promoters of Non-Haem Iron Absorption, Nutrients, 9, pp. 609. DOI: 10.3390/nu9060609.

7. Kapustian A., Cherno N. (2017), Chelate forms of biometalls. Theoretical aspects of obtaining and characteristics, Food science and technology, 11(1), pp. 37-49, DOI: 10.15673/fst.v11i1.297.

8. Belayet Hossain M.D., Saidul Islam M., Rafiqul Islam M., Abdus M.D. et al. (2012), Synthesis and characterization of mixed ligand complexes of $\mathrm{Co}$ (II) and $\mathrm{Fe}$ (III) ions with maleic acid and heterocyclic amines, Journal of Bangladesh Chemical Society, 25(2), pp. 139-145, DOI: 10.3329/jbcs.v25i2.15066.

9. Zolotareva N.V., Semenov V.V., Petrov B.I. (2013), Preparation of Water-Soluble Iron and Manganese Chelates with Oxyethylidenediphosphonic Acid, Russian Journal of General Chemistry, 83(11), pp. 1985-1989, DOI: 10.1134/S1070363213110030.

10. Scheglova N.V., Pechnikova A.S., Shevchenko A.I. (2014), Smeshannoligandnyie kompleksyi kobalta (III) s etilendiaminom i etilendiamintetrauksusnoy kislotoy $\mathrm{v}$ vodnyih rastvorah, Vestnik Kazanskogo tehnologicheskogo universiteta, 17(17), pp. 5659.

11. Nikolaeva L.S., Semenov A.N., Burova L.I. (2011), Smeshannoligandnoe kompleksoobrazovanie ionov kaltsiya i magniya s geparinom i glitsinom, Zhurn. neorg. Himii, 56(4), pp. 689-696, DOI: 10.1134/S003602361104022X.

12. Zolotuhina N.A. (2015), Kompleksyi perehodnyih metallov s organicheskimi ligandami, Polzunovskiy vestn IK, 4(2), pp. 58-60.

13. Verma Sh. (2015), Equilibrium study and Stability constants of mixed Ligand complexes of Biomolecules and Amino acids with Metal ions by Potentiometric method, Research Journal of Chemical Sciences, 5(3), pp. 42-48.

14. Rabindra P., Mohan A. (2000), Synthesis and characterization of mixed ligand complexes of bio-metals with pyrimidine nucleoside (uridine) and amino acids, Proc. Indian Acad. Sci. (Chem. Sci.), 112(6), pp. 593-600, DOI: 10.1007/BF02704366.

15. Gandham Hima Bindu, Gollapalli Nageswara Rao (2012), Mixed ligand complexes of essential metal ions with L-glutamine and succinic acid in sodium dodecyl sulfatewater mixtures, J. Serb. Chem. Soc., 77(4), pp. 453-63, DOI: 10.2298/JSC110201177B.

16. Kapustian A.I., Cherno N.K. (2015), Perspektivyi ispolzovaniya biologicheski aktivnyih bakterialnyih gidrolizatov dlya nutritivnoy podderzhki naseleniya $\mathrm{s}$ rastroystvami immunnoy sistemyi, Pischevaya nauka i tehnologiya, 2(31), pp. 18-25, DOI: $10.15673 / 2073-8684.31 / 2015.44263$.

17. Cherno N., Kapustyan A. (2016), Immunological properties of the bacterial origin compounds, Food science and technology, 10(3), pp. 19-28, DOI: 10.15673/fst.v10i3.175.

18. Traub S., Von S. Aulock, Hartung T., Hermann C. (2006), MDP and other muropeptides - direct and synergistic effects on the immune system, J Endotoxin Res, 12, pp. 69-85, DOI: 10.1179/096805106X89044.

19. Qingshan Lv. et al. (2012), MDP Up-Regulates the Gene Expression of Type I Interferons in Human Aortic Endothelial Cells, Molecules, 17, pp. 3599-3608, DOI: 10.3390/molecules17043599. 
20. Matsui K., Ikeda R. (2014), Peptidoglycan in combination with muramyldipeptide synergistically induces an interleukin-10-dependent $\mathrm{T}$ helper 2-dominant immune response, Microbiol Immunol, 58, pp. 260-265, DOI: 10.1111/1348-0421.12139.

21. Matsumoto S. et al. (2009), A component of polysaccharide peptidoglycan complex on Lactobacillus induced an improvement of murine model of inflammatory bowel disease and colitis-associated cancer, Immunology, 128, pp. 170-80, DOI: 10.1111/j.13652567.2008.02942.x.

22. Semak I.V., Zyiryanova T. N., Gubich O. I. (2007), Biohimiya belkov, Minsk.

23. Kapustian A.I., Cherno N.K., Pukas A.S. (2019), Rozroblennia metodu vyznachennia funktsionalnykh kharchovykh inhrediientiv muropeptydnoho pokhodzhennia $\mathrm{u}$ bakterialnykh dezintehratakh, Naukovi pratsi NUKhT, 25(62), pp. 157-164.

24. Morris D.L. (1948). Quantitative Determination of Carbohydrates With Dreywood's Anthrone Reagent, Science, 107(2775), pp. 254-255, DOI: 10.1126/science.107.2775.254.

25. Starr J.N., Westhoff G. Lactic Acid (2014), Ullmann's Encyclopedia of Industrial Chemistry, Wiley, DOI: 10.1002/14356007.a15_097.pub3.

26. Kapustian A.I., Cherno N.K. (2019), Vyznachennia kompleksoutvoriuvalnoi zdatnosti zmishanolihandnykh orhanichnykh system po vidnoshenniu do yoniv metaliv, Naukovyi visnyk Lvivskoho natsionalnoho universytetu veterynarnoi medytsyny ta biotekhnolohii im. S.Z. Hzhytskoho, 21(91), pp. 130-135.

27. Klenin V.I., Schegolev S.Yu., Lavrushin V.I. (1977), Harakteristicheskie funktsii svetorasseyaniya dispersnyih sistem, Saratov.

28. Mophan N., Vinitnantharat S., Somsook E. (2010), Enhancing iron (III) solubility using cassava and arrowroot starch, Science Asia, 36, 172-173, DOI: 10.2306/scienceasia1513-1874.2010.36.172.

29. Tarasevich B.N. (2012), IK-spektryi osnovnyih klassov organicheskih soedineniy, Moscow.

30. Neudachina L.K., Lakiza N.V. (2014), Fiziko-himicheskie osnovy primeneniya koordinacionnyh soedinenij, Ekaterinburg.

31. Nakamoto K. (1966), Infrakrasnyie spektryi neorganicheskih $i$ koordinatsionnyih soedineniy, Moscow. 